\title{
Small Scale Synthesis of Labeled Diphenyl and Its Binding to Mouse Liver Microsomes
}

\author{
Akira Tanaka, Kazushige Morimoto* and Tsutomu Yamaha* \\ Showa College of Pharmaceutical Sciences \\ 3-3165, Higashi-tamagawagakuen, Machida-shi, Tokyo 194, Japan \\ ${ }^{*}$ National Institute of Hygienic Sciences \\ 1-18-1, Kamiyoga, Setagaya-ku, Tokyo 158, Japan
}

Received July 14, 1993

\begin{abstract}
For safety evaluation of diphenyl, a food additive, in Japan, labeled diphenyl was synthesized by reaction of thallium $(I)$ bromide with phenylmagnesium bromide which is prepared from bromobenzene- $\mathrm{U}-{ }^{14} \mathrm{C}$ in ether. The formation of labeled diphenyl in high yield made it possible to study the binding of diphenyl to mouse hepatic microsomes. Diphenyl with high specific activity formed the covalent binding to microsomes after metabolic activation. However, effects of two inducers, benzo (a) pyrene and KC-500, on the binding activitiy of diphenyl were not clear under our experimental conditions. The data reported here seem to be valuable from the view point on safety evaluation on food additives.
\end{abstract}

Key Words: diphenyl, Grignard reaction, thallium(I) bromide, hepatic microsomes, mouse, metabolic activation, covalent binding

\section{Introduction}

Diphenyl, a fungistat for preserving fruit, is widely used as a food additive in Japan. Diphenyl forms the nucleus of polychlorinated biphenyls (PCBs), a group of highly toxic chemicals in the environment. In general toxicities of chemicals appear to be related to their binding to target cell constituents. Although diphenyl is a low toxic substance, safety evaluation of food additives is one of the most important problems in our daily life from the point of national health. This paper deals with the high yield synthesis of ${ }^{14} \mathrm{C}$-labeled diphenyl and the in vitro binding of labeled diphenyl to mouse liver microsomes which is a useful way for presuming its in vivo toxicity.

\section{Materials and Methods}

$2 \cdot 1$ Chemicals

Bromobenzene-U- ${ }^{14} \mathrm{C}$ (37 MBq, $185 \mathrm{MBq} /$ mmol) was purchased from Radiochemical Centre, Amersham, England. Other chemicals and solvents were of reagent grade purity. Pure diphenyl (mp $70.5^{\circ} \mathrm{C}$ ) was obtained by recrystallization of a commercial product from methanol. Benzo (a) pyrene was obtained from Wako Pure Chemicals. Kanechlor-500 (KC-500) was a gift from Dr. Kaneko' ${ }^{1}$.

2.2 Chromatography and radioactivity measurement

Commercially available silica gel plates- $F$ (Wako or Merck) were used for thin-layer chromatography (TLC). Spots on the chromatogram were detected under a UV lamp. Radiochromatograms were scanned with a radiochromatoscanner TRM-1B (Aloka). Measurement of radioactivity was made using an LSC-651 counter (Aloka). 


\section{$2 \cdot 3$ Synthesis of ${ }^{14} \mathrm{C}$-diphenyl}

This preparation was carried out under a stream of dry nitrogen. A solution of $1.1 \mathrm{~g}$ labeled bromobenzene in $3.0 \mathrm{ml}$ tetrahydrofuran (THF) was added dropwise to a stirring suspension of $175 \mathrm{mg}$ magnesium turnings in $0.8 \mathrm{ml}$ THF. Stirring and slight warming were sufficient to initiate the reaction. After $2 \mathrm{~h}$ under reflux all magnesium turnings dissolved completely. To the prepared Grignard reagent was added $3 \mathrm{~g}$ powdered thallium bromide and then $3.4 \mathrm{ml}$ benzene. The mixture was heated under reflux for $4 \mathrm{~h}$, during which thallium bromide blackened. The reaction mixture was filtered and the insoluble materials were washed thoroughly with ether. The ether washings were combined with the filtrate. The combined ether solution was washed with $0.1 \mathrm{~N}$ hydrochloric acid, water and dried over sodium sulfate overnight. Reaction route is shown in Chart 1.
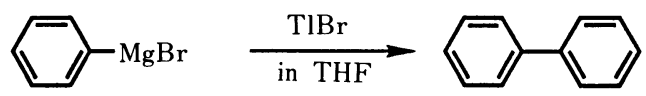

Chart 1 Synthesis of ${ }^{14} \mathrm{C}$-diphenyl.

The ether was removed to give residual white crystals. The crystals were purified through an alumina column $(2.5$ long $\times 0.8 \mathrm{~cm}$ diameter $)$ using benzene as an eluent. The first $10 \mathrm{ml}$ eluate gave $485 \mathrm{mg}$ crude diphenyl, but the second $25 \mathrm{ml}$ eluate did not include any product. Crude ${ }^{14} \mathrm{C}$ diphenyl was dissolved in $3 \mathrm{ml}$ hexane and purified through a silica gel column (3.0long $\times 3.5$ $\mathrm{cm}$ diameter). Hexane was used as an eluent and each $35 \mathrm{ml}$ hexane fraction contained the following weight of pure labeled diphenyl, i.e. fractions $1: 330 \mathrm{mg}$ and $2: 147 \mathrm{mg}$, respectively. Yield 93.5\%. Radiochemical yield was $94.0 \%$. The radiochromatogram of synthetic diphenyl showed a single peak as shown in Fig. 1 and the same $R_{\mathrm{f}}$ value and melting point as the authentic sample.

The following $R_{\mathrm{f}}$ values were obtained : 0.42 in

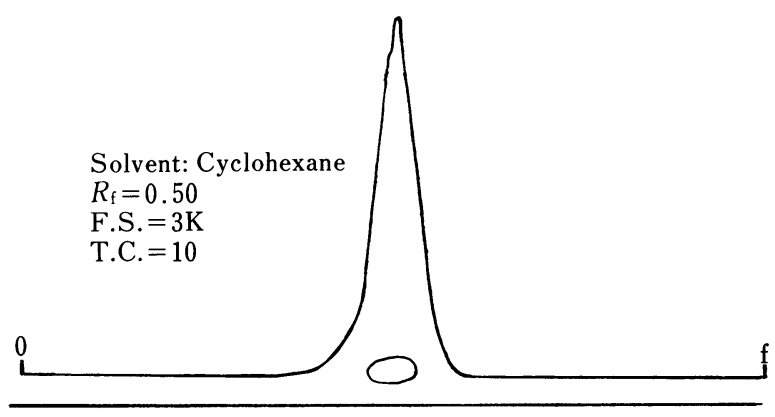

Fig. 1 Radiochromatogram of ${ }^{14} \mathrm{C}$-diphenyl.

hexane, 0.50 in cyclohexane and 0.79 in carbon tetrachloride. The diphenyl (sp. act. $72.9 \mathrm{kBq} /$ $\mathrm{mg}$ ) thus obtained was used in next experiments.

\subsection{Animal treatment and isolation of hepatic microsomes}

Male weanling ddy mice weighing 17.5-18.5 $\mathrm{g}$ were housed in animal cages and allowed to free access to standard diet and water. $\operatorname{Benzo}(a)$ pyrene(BP, $1.42 \mathrm{mg} / \mathrm{kg}$ ) or KC-500 $(100 \mathrm{mg} / \mathrm{kg})$ in olive oil, was injected i.p. into each of seven mice. Eight control mice received i.p. a corresponding volume of olive oil $(0.2 \mathrm{ml} / \mathrm{mouse})$. After the injection of the two inducers and olive oil alone to mice, the mice were starved for $24 \mathrm{~h}$ to lower glycogen levels and killed by decapitation.

Liver microsomes were prepared from mice according to the modified method of Potter et al. ${ }^{2)}$. Each liver was perfused via the hepatic portal vein with ice-cold isotonic saline. Two or three livers were combined and homogenated in 3 volumes of $1.15 \% \mathrm{KCl}$ containing $20 \mathrm{mM}$ Tris$\mathrm{HCl}$ buffer, $\mathrm{pH}$ 7.4. The microsomal fraction was harvested by differential centrifugation essentially as described in the reference ${ }^{2}$. All microsomal fractions as, pellets were combined and resuspended in 0.1 $\mathrm{M}$ phosphate buffer ( $\mathrm{pH} 7.4)$ and its suspension was used as a fraction of microsomes. Microsomal protein was assayed by the Folin's method. 


\section{$2 \cdot 5$ Binding study}

Metabolic activation was done in the following reaction mixture : NADP $0.5 \mu \mathrm{M}$, glucose-6phosphate $10 \mu \mathrm{M}, \quad \mathrm{MgCl}_{2} 25 \mu \mathrm{M}$, glucose-6phosphate dehydrogenase $5-\mathrm{U},{ }^{14} \mathrm{C}$-diphenyl $43 \mu \mathrm{g}$ $\left(1.88 \times 10^{5} \mathrm{dpm}\right)$ in $0.1 \mathrm{ml}$ methanol and $0.1 \mathrm{M}$ phosphate buffer ( $\mathrm{pH} 7.4)$ in a final volume of $1.0 \mathrm{ml}$.

The reaction mixture was incubated under aerobic conditions at $37^{\circ} \mathrm{C}$ in a shaking water bath. The reaction was stopped at various intervals by addition of $1 \mathrm{ml}$ ice-cold 10\% trichloroacetic acid (TCA). The solution was allowed to stand under ice cooling for $45 \mathrm{~min}$. The precipitates were centrifuged and washed twice with 5\% TCA, once with $80 \%$ methanol, hot methanol, a mixture of methanol and ether $(1: 1)$ and finally $80 \%$ methanol.

The washed precipitates were dissolved in $1 \mathrm{ml}$ Soluene 100 and an aliquot of the Soluene solution was added to toluene scintillator for radioactivity counting.

\section{Results and Discussion}

In 1954 Murakami and $\mathrm{Akagi}^{3)}$ published the synthetic method of non-labeled diphenyl by coupling of benzene with $N$-nitrosoacetanilide. Thereafter, Koyama and his coworkers ${ }^{4}$ reported the synthesis of diphenyl-(phenyl $\left.-{ }^{14} \mathrm{C}\right)$ and its improved synthesis by reaction of benzene with $N$ nitrosoacetanilide(phenyl $-{ }^{14} \mathrm{C}$ ), but the total yield was not so high with a small yield of $o$-terphenyl(phenyl $-{ }^{14} \mathrm{C}$ ) as a by-product, and their synthetic method required long steps for obtaining ${ }^{14} \mathrm{C}$ diphenyl. Ullmann reaction ${ }^{5), 6)}$, Gomberg reaction $^{7}$, thermal decomposition of benzene ${ }^{8}$, reaction of fluorobenzene with phenyl lithium ${ }^{9}$, coupling of aryl halide in the presence of tris (triphenylphosphine) nickel ${ }^{10)}$ and Grignard reaction of phenylmagnesium and halogenobenzene ${ }^{11)}$ are conceivable as synthetic methods of ${ }^{14} \mathrm{C}$-diphenyl. However, these reactions are not expected very high yields of the desired labeled compound. For instance, Kende et al. $\left.{ }^{10}\right)$ synthesized diphenyl in $73 \%$ yield from bromobenzene in the presense of nickel catalysis in dimethylformamide and Hoizumi and Moriya ${ }^{12)}$ synthesized ${ }^{14} \mathrm{C}$-diphenyl in about $64 \%$ yield by Ullmann reaction ${ }^{5}$. This time the authors could obtain the objective product in high yield by the coupling reaction of ${ }^{14} \mathrm{C}$-phenylmagnesium bromide derived from bromobenzene- $\mathrm{U}-{ }^{14} \mathrm{C}$ in the presence of thallium bromide ${ }^{13)}$.

Synthesized diphenyl- $U-{ }^{14} \mathrm{C}$ showed high specific activity enough for binding studies of diphenyl to mouse liver microsomes. Binding of ${ }^{14} \mathrm{C}$ diphenyl to mouse liver microsomes reached constant at about 20 min after incubation as shown in Fig. 2.

The binding of ${ }^{14} \mathrm{C}$-diphenyl-derived radioactivity to the BP treated microsomes was 1.22 times higher than that to the control for $60 \mathrm{~min}$ incubation (Table 1). Table 2 shows clearly that

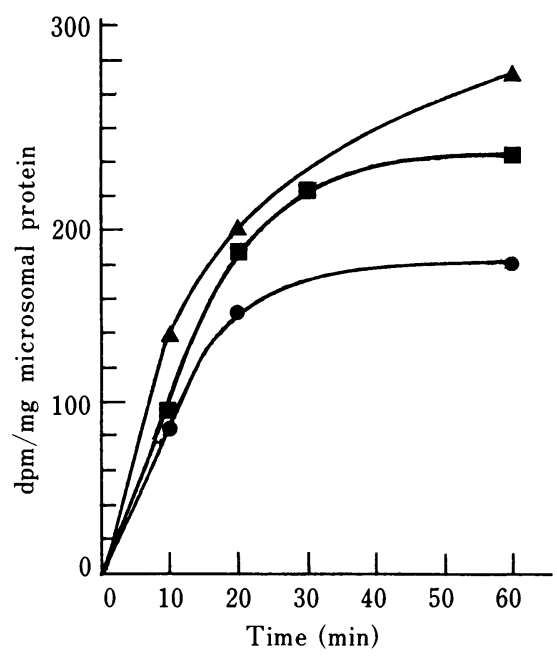

Fig. 2 In vitro covalent binding of ${ }^{14} \mathrm{C}$-diphenyl to mouse liver microsomes pretreated with a single intraperitoneal injection of benzo $(a)$ pyrene $(1.0 \mathrm{mg})$. Points represent means of two or three mice.

Sample 1: $\mathbf{\Delta}$, Sample 2: Sample 3: 
Table 1 Covalent binding of ${ }^{14} \mathrm{C}$-diphenyl to mouse liver microsomes

\begin{tabular}{c|c|c}
\hline \multirow{2}{*}{$\begin{array}{c}\text { Reaction time } \\
(\mathrm{min})\end{array}$} & \multicolumn{2}{|c}{$\begin{array}{c}\text { Diphenyl bound dpm/mg } \\
\text { microsomes protein }\end{array}$} \\
\cline { 2 - 3 } & Control & Benzo $(a)$ pyrene \\
\hline 10 & $127.7 \pm 18.0$ & $106.2 \pm 16.4$ \\
20 & $192.3 \pm 19.7$ & $179.3 \pm 13.9$ \\
30 & $191.8 \pm 18.6$ & $208.5 \pm 21.4$ \\
60 & $196.2 \pm 22.2$ & $240.8 \pm 28.2$ \\
\hline
\end{tabular}

Values are means of 3 determinations $\pm \mathrm{S}$. E. from individual mice.

Eight and seven mice were used for control and benzo $(a)$ pyrene-treated experiments, respectively.

NADPH is essential for binding activity of diphenyl. The results suggest the in vitro covalent binding of diphenyl to TCA-insoluble macromolecules after metabolic activation by a monooxygenase system in hepatic microsomes. Table 1 suggests that the ${ }^{14} \mathrm{C}$-binding in the BP-treated microsomes is a little higher than that of the control, but the difference between the two groups was not statistically significant, because of large variations of the values. Binding amounts at $30 \mathrm{~min}$ were 0.28 $\mathrm{ng} / \mathrm{mg}$ protein in the control and $0.30 \mathrm{ng} / \mathrm{mg}$ protein in the BP-pretreated group, respectively. Binding of acetaminophen ${ }^{14)}$, furosemide ${ }^{14)}$ and $\mathrm{KC}-300^{15)}$ to mouse liver microsomes is reported to be $0.61 \pm 0.12 \mathrm{nmol} / \mathrm{mg}$ protein $/ 30 \mathrm{~min}, 1.25$ $\pm 0.11 \mathrm{nmol} / \mathrm{mg}$ protein $/ 15 \mathrm{~min}$ and $3078 \mathrm{dpm} /$ $\mathrm{mg}$ protein/60 min. Binding ratio of diphenyl to mouse hepatic microsomes is presumed as about $40 \%$ of acetaminophen and about one-fifteenths of $\mathrm{KC}-300$ on the basis of the above reference data.

Two inducers, KC-500 and BP did not give any effect on the binding of diphenyl to liver microsomes. Diphenyl is known to be low toxic in mammals and excreted rapidly after reaction of Phase I and Phase II reactions (hydroxylation and conjugation) in experimental animals ${ }^{16-18}$. No significant accumulation was observed after
Table 2 Requirements for covalent binding of ${ }^{14} \mathrm{C}$-diphenyl to mouse liver microsomes

\begin{tabular}{l|c|c|l}
\hline \multirow{2}{*}{ Reaction mixture } & \multicolumn{3}{|c}{$\begin{array}{l}\text { Diphenyl bound (dpm/ } \\
\text { mg protein/60 min) }\end{array}$} \\
\cline { 2 - 4 } & Control & $\begin{array}{c}\text { Benzo }(a) \\
\text { pyrene }\end{array}$ & KC-500 \\
\hline Complete system & 168 & 223 & 118 \\
\hline $\begin{array}{l}\text {-NADPH } \\
\text { generating system }\end{array}$ & $22(87)$ & $32(86)$ & $26(78)$ \\
\hline
\end{tabular}

Figures in parentheses show percent inhibition. $\mathrm{BP}(1.42 \mathrm{mg} / \mathrm{kg})$ or $\mathrm{KC}-500(100 \mathrm{mg} / \mathrm{kg})$ in olive oil, was injected into each of seven mice. Eight control mice received the corresponding volume of olive oil (i. p. $0.2 \mathrm{ml} /$ mouse).

oral administration of diphenyl in comparison with PCBs which show a long retention in the body. Ortho-phenylphenol (OPP), a hydroxylated product of diphenyl, and sodium salt of OPP (OPPNa) are listed in the Japanese compendium of food additives, and high incidence of urinary bladder tumor is reported following OPP- and OPPNa-feeding in rats ${ }^{19}$. We reported the correlation between the DNA damage in urinary bladder epithelium and the urinary 2-phenyl-1,4-benzoquinone levels from F344 rats fed OPPNa ${ }^{20}$.

While no papers are reported on the incidence of tumors in mice ${ }^{21}$, although the metabolic pattern of OPP is the same in rats and mice.

From the view point of toxicology, toxicities of chemicals seem to be much related to the binding to glutathione (GSH) and the important macromolecules such as nucleic acids and proteins. Safety evaluation of a food additive by the in vitro assay is becoming more important in the field of living-life related substances. The data seem to be valuable in knowing relationships between the covalent binding to cells and toxicity of chemicals. 


\section{References}

1) Kaneko, M., Morimoto, K. and Nambu, S. : Water Res., 10, 157-163 (1976)

2) Potter, W. Z., Davis, D. C., Mitchell, J. R., Jollow, D. J., Gillet, J. R. and Brodie, B. B. : J. Pharm. Exptl. Therap., 187, 203-210 (1973)

3) Murakami, M. and Akagi, K. : Nippon Kagaku Kaishi, 75, 532-535 (1954) (in Japanese)

4) Koyama, H., Morikawa, N., Migita, M., Ito, R. and Tsuchihashi, G. : Radioisotopes, 9, 112-114 (1960) ; ibid., 11, 107-109 (1962)

5) Forrest. J. : J. Chem. Soc., 1960, 574-580

6) Fanta, P. E. : Synthesis, 1974, 9-21

7) Elks, J., Hawarth, J. W. and Hey, D. H. : J. Chem. Soc., 1940, 1284-1286

8) Wibaut, J. P., Ramijin, H. M. and Willink, H. D. T. : Rec. Trav. Chim., 53, 584-590 (1934)

9) Jenny, E. F. and Robert, J. D. : Helv. Chim. Acta, 38, 1248-1254 (1955)

10) Kende, A. S., Liebesk, L. S. and Braitsch, D. M. : Tetrahedron Lett., 1975, 3375-3378

11) Kharsch, M. S. and Field, E. K. : J. Am. Chem. Soc., 63, 2316-2320 (1941)

12) Hoizumi, K. and Moriya, T. : J. Label. Compds., 10, 499-508 (1974)
13) McKillop, A., Elson, L. F. and Tayler, E. C. : Tetrahedron, 26, 4041-4050 (1970)

14) Mitchell, J. R., Nelson, W. L., Potter, W. Z., Sasame, H. A. and Jollow, D. J. : J. Pharm. Exptl. Therap., 199, 41-52 (1976)

15) Shimada, T. : Bull. Environ. Contam., 16, 25-32 (1976)

16) Halpaap, K., Horning, M. G. and Horning, E. C. : J. Chromatog., 166, 479-490 (1978)

17) Meyer, T., Aarbakke, J. and Scheline, R. R. : Acta Pharm. Toxicol., 39, 412-418 (1976); 40, 201-208 (1977)

18) Haugen, D. A. : Drug Metab. Disposit., 9, 212218 (1981)

19) Hiraga, K. and Fujii, T. : Fd. Cosmet. Toxic., 19, 303-310 (1981) ; 22, 865-870 (1984)

20) Morimoto, K., Sato, M., Fukuoka, M., Hasegawa, R., Takahashi, T., Tsuchiya, T., Tanaka, A., Takahashi, A. and Hayashi, Y. : Carcinogenesis, 10, 1823-1827 (1989)

21) Innes, J. R. M., Ulland, B. M., Valerio, M. G., Petrucelli, L., Fishbein, L., Hart, E. R., Pallotta, A. J., Bates, R. R., Falk, H. L., Gart, J. J., Klein, M., Mitchell, I. and Peters, J. : J. Natl. Cancer Inst., 42, 1101-1114 (1969)

要旨

\section{${ }^{14} \mathrm{C}$-標識ジフェニルの小規模合成とマウス肝ミクロソームへの結合}

田中・彰, 森本和滋*, 山羽 力*,†

昭和薬科大学 194 東京都町田市玉川学園 3-3165

*国立衛生試験所 158 東京都世田谷区上用賀 1-18-1

わが国で食品添加物として使用されているジフェニルの安全性評価のために，標識ジフェニルの 合成をおこなった。まず臭化べンゼン $-\mathrm{U}-{ }^{14} \mathrm{C}$ を原料として，臭化フェニルマグネシウムを得た 後，このグリニャール試薬を無水テトラヒドロフラン中で臭化タリウム（I）の存在下，カップリ ング反応をおこなうことにより，約 $94 \%$ 高収率で目的の ${ }^{14} \mathrm{C}-$ ジフェニルを得ることができた。

合成した高比放射能の標識ジフェニルは，そのマウス肝ミクロソームへの結合研究を可能にし

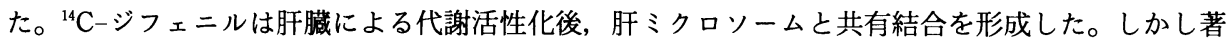
者らの実験条件下では，誘導剤であるベンゾピレンとカネクロール（KC-500）投与による影響は 明らかではなかった。ここに報告したデータは，食品添加物の安全性を評価する見地から，非常に 有用と考えられる。

\footnotetext{
†現所属：(財)ヒューマンサイエンス振興財団 103 東京都中央区日本橋人形町 2-25-13
} 